\title{
Penguatan Kader Rehabilitasi Berbasis Masyarakat Guna Mewujudkan Masyarakat yang Inklusi
}

\author{
Arni Surwanti1*, Warih Andan Puspitosari² \\ 1. Magister Manajemen, Program Pascasarjana, Universitas Muhammadiyah Yogyakarta, Jl. Brawijaya Tamantirto Yogyakarta \\ Email: arni_surwanti@umy.ac.id \\ DOI: $10.18196 / p p m .32 .199$
}

\begin{abstract}
Abstrak
Partisipasi aktif keluarga dan masyarakat dalam mewujudkan masyarakat yang inklusi sangat diperlukan ketika konsep layanan melalui panti menjadikan penyandang disabilitas harus terpisah dengan keluarga dan lingkungannya. Kelompok Berbasis Masyarakat/RBM yang dimiliki desa masih belum optimal dalam memberikan layanan pada penyandang disabilitas. Penyandang disabilitas di Desa Panggungharjo masih menghadapi persoalan yang berkenaan dengan kesejahteraan karena kesulitan mendapatkan pekerjaan. Produktivitas tenaga kerja penyandang disabilitas masih rendah karena belum mendapatkan kesempatan pelatihan kerja. Program Kemitraan Masyarakat diharapkan dapat menyelesaikan permasalahan tersebut dengan beberapa hal. Pertama, melakukan peningkatan kualitas kader kelompok rehabilitasi berbasis masyarakat, terutama menekankan cara melakukan pendataan, referral, dan advokasi. Kedua, pendampingan pada Kelompok Rehabilitasi Berbasis Masyarakat serta penyusunan program dan kegiatan kelompok rehabilitasi berbasis masyarakat yang menjamin adanya layanan yang dapat diakses oleh penyandang disabilitas. Ketiga, peningkatan kapasitas penyandang disabilitas melalvi pemberian pelatihan motivasi, pelatihan keterampilan shibori, dan manajemen kewirausahaan pada penyandang disabilitas. Hasil kegiatan ini menunjukkan bahwa kader kelompok rehabilitasi berbasis masyarakat telah mampu melakukan pendataan, referral, advokasi, serta peningkatan ketrampilan penyandang bagi penyandang disabilitas melalui pelatihan sibori. Implikasi dari kegiatan ini adalah bahwa penanganan penyandang disabilitas tidak perlu menekankan pada peran panti, tetapi penanganan di masyarakat dapat menjadi pilihan dalam penanganan penyandang disabilitas.
\end{abstract}

Kata Kunci: Penyandang Disabilitas, Kader, Kelompok Rehabilitasi Berbasis Masyarakat.

\section{Pendahuluan}

Desa Panggungharjo merupakan salah satu desa yang berada dalam wilayah Kabupaten Bantul dan memiliki penduduk sejumlah 25.727 orang. Secara administratif Desa Panggungharjo terdiri atas 14 pedukuhan yang terbagi menjadi 118 RT[1]. Pada saat ini, penyandang disabilitas di Desa Panggungharjo, Sewon, Bantul, Yogyakarta sebagaimana juga yang terjadi pada di desa lain di Propinsi Daerah Istimewa Yogyakarta masih menghadapi persoalan yang berkenaan dengan kesejahteraan. Karakteristik penyandang disabilitas di Desa Panggungharjo, sebagaimana rata-rata kondisi penyandang disabilitas di Kabupaten Bantul, ialah masih menghadapi masalah psikhologis, berasal dari keluarga yang tingkat sosial ekonomi dan kesehatannya rendah, tingkat pendidikan umumnya rendah, produktivitas sumber daya manusia penyandang disabilitas relatif rendah sehingga kesulitan mendapatkan pekerjaan.

Kementerian Sosial sebagai leading sector penanganan masalah disabilitas telah menggulirkan kebijakan pemberdayaan disabilitas yang menitikberatkan pada partisipasi aktif keluarga dan masyarakat sebagai kristalisasi model saat ini. Model diarahkan pada semua tindakan untuk menggunakan dan membangun sumber daya masyarakat termasuk penyandang disabilitas, keluarga, pemerintah desa, dan masyarakat di sekitarnya. Paradigma ini memandang keluarga dan masyarakat sebagai kekuatan utama sumber daya rehabilitasi bagi penyandang disabilitas. Konsep rehabilitasi berbasis masyarakat diperkenalkan pertama kali oleh World Health Organization, [10] yaitu suatu strategi meningkatkan akses layanan rehabilitasi bagi penyandang disabilitas dengan menggunakan sumber daya lokal. Pergeseran paradigma dalam layanan rehabilitasi sosial bagi penyandang disabilitas dengan lebih memberdayakan keluarga dan masyarakat juga sejalan dengan UU No. 19 tahun 2011 pasal 26. Inti dari pasal tersebut 
adalah bahwa habilitasi dan rehabilitasi serta pelayanan dan program bagi penyandang disabilitas harus mudah dijangkau oleh penyandang disabilitas di lingkungannya dengan melibatkan partisipasi keluarga dan masyarakat. Sesuai pasal 92 UU No. 8 tahun 2016 tentang penyandang disabilitas, yang dimaksud dengan rehabilitasi sosial adalah pelatihan motivasi dan diagnosis psikososial; perawatan dan pengasuhan; pelatihan vokasional dan pembinaan kewirausahaan; bimbingan mental spiritual yang dilaksanakan secara persuasif, motivatif, dan koersif oleh keluarga, masyarakat, dan institusi sosial.

Kebijakan pemerintah untuk meningkatkan fungsi keluarga dan masyarakat merupakan salah satu cara agar pemerintah dan masyarakat dapat bersama-sama bahu-membahu meningkatkan jangkauan layanan sehingga akan lebih banyak penyandang disabilitas yang terjangkau oleh layanan. Kondisi ini juga akan mendukung terbentuknya masyarakat inklusif, yaitu masyarakat yang memiliki penerimaan, penghormatan, perlindungan, dan pemenuhan hakhak penyandang disabilitas dalam berbagai aspek kehidupan. Masyarakat inklusif memberikan beberapa keunggulan, seperti penyandang disabilitas akan memiliki akses terhadap pelayanan yang mereka butuhkan, sementara mereka tetap berada didalam masyarakat, berinteraksi, berintegrasi, dan menikmati kehidupan bersama anggota masyarakat yang lainnya. Kondisi ini memungkinkan terciptanya kemandirian (self-reliance) pada penyandang disabilitas, keluarga, dan masyarakat tinggal [8].

Salah satu upaya untuk membangun masyarakat inklusif dan merangsang partisipasi keluarga dan masyarakat adalah dengan cara memfasilitasi penyandang disabilitas dan keluarganya untuk melakukan aktivitas bersama-sama dalam satu tempat yang aksesibel atau mudah dijangkau di tengah masyarakat dengan memanfaatkan sumber-sumber yang ada di masyarakat. Aktivitas ini akan menyinergikan berbagai komponen di masyarakat dalam membangun kesetaraan dan pemenuhan hak-hak penyandang disabilitas. Pembentukan Kelompok Rehabilitasi Berbasis Masyarakat (kelompok RBM) akan menjadi wadah partisipasi aktif penyandang disabilitas, keluarga, masyarakat, dan pemerintah desa dalam kegiatan rehabilitasi sosial. Kelompok RBM ini juga membangun struktur kesinambungan pelayanan rehabilitasi sosial penyandang disabilitas yang sebelumnya dilakukan oleh lembaga kesejahteraan sosial. Inti aktivitas kelompok rehabilitasi berbasis masyarakat/RBM ini adalah menguatkan penyandang disabilitas, keluarga, dan masyarakat melalui peningkatan kapasitas, pembangunan kemandirian, pembangunan sistem rujukan, pengembangan upaya preventif dan promotif bagi masalah disabilitas. Kelompok rehabilitasi berbasis masyarakat ini dapat berperan dalam pengentasan masalah disabilitas dan menjadi bagian dari pengentasan masalah kemiskinan di masyarakat.

Kelompok Rehabilitasi Berbasis Masyarakat (RBM) yang terbentuk di Desa Panggungharjo ini terdiri atas penyandang disabilitas dan keluarganya, ibu-ibu PKK, serta aparat pemerintah desa. Menurut Direktorat Rehabilitasi Sosial Penyandang Disabilitas, Direktorat Jenderal Rehabilitasi Sosial Kementerian Sosial Republik Indonesia [2], kelompok Rehabilitasi Berbasis Masyarakat (Community Based Rehabilitation/CBR) seharusnya bisa melakukan pemutakhiran data, rujukan, dan advokasi berdasarkan strategi untuk rehabilitasi, persamaan peluang, pengurangan kemiskinan, dan inklusi sosial bagi penyandang disabilitas.

Kelompok Rehabilitasi Berbasis Masyarakat di Desa Panggungharjo baru terbentuk di awal tahun 2019 dengan melibatkan penyandang disabilitas dan keluarganya, tokoh masyarakat, PKK, dan pemerintah desa sebagai koordinator sekaligus melakukan supervisi. Sebagai lembaga yang baru, kelompok Rehabilitasi Berbasis Masyarakat ini masih belum tampak perannya dalam menangani permasalahan penyandang disabilitas [9] 
Hal ini disebabkan kelompok ini belum baik dalam memahami berbagai isu tentang permasalahan penyandang disabilitas, masih rendahnya kemampuan kelompok ini dalam menjalankan perannya sebagai lembaga yang dapat melakukan pemutakhiran data, melakukan referal kebutuhan-kebutuhan penyandang disabilitas pada berbagai layanan pemerintah, serta melakukan advokasi untuk pemenuhan hak-hak penyandang disabilitas. Demikian pula perannya dalam menguatkan penyandang disabilitas dan keluarganya melalui peningkatan kapasitas, pembangunan kemandirian, serta pengembangan upaya preventif dan promotif bagi masalah disabilitas masih perlu ditingkatkan dalam upaya melalukan rehabilitasi sosial.

\section{Metode Pelaksanaan}

Program pengabdian masyarakat melalui Program Kemitraan Masyarakat ini dilaksanakan dengan beberapa kegiatan:

a. Penguatan Kelompok Rehabilitasi Berbasis Masyarakat memahami berbagai isu tentang permasalahan penyandang disabilitas, khususnya terkait rehabilitasi sosial.

Kelompok rehabilitasi berbasis masyarakat yang beranggotakan kader PKK dan penyandang disabilitas, dan perwakilan pemerintah desa mendapatkan pemahaman tentang peraturan perundangan pemenuhan hak penyandang disabilitas, pemahaman tentang cara penanganan penyandang disabilitas, dan tentang peran komunitas untuk upaya penghapusan kekerasan terhadap perempuan dan anak disabilitas.

b. Pendampingan penyusunan program dan kegiatan kelompok rehabilitasi berbasis masyarakat melakukan pemutakhiran data, melakukan referal kebutuhan-kebutuhan penyandang disabilitas pada berbagai layanan pemerintah, dan melakukan advokasi untuk pemenuhan hak-hak penyandang disabilitas.Pada kegiatan ini, telah dilakukan pendampingan pendataan penyandang disabilitas di Desa Panggungharjo dengan menggunakan basis dusun. Kader Rehabilitasi Berbasis Masyarakat dibagi berdasarkan jumlah dusun yang ada. Mereka diberi tanggung jawab untuk melakukan pendataan dengan formulir pendataan yang telah disusun.

c. Pemberdayaan penyandang disabilitas dan keluarganya dilakukan melalui peningkatan kapasitas dan pembangunan kemandirian, untuk meningkatkan kesejahteraannya melalui pelatihan keterampilan pada penyandang disabilitas sehingga mereka memiliki kemandirian secara ekonomi. Pelatihan yang diberikan adalah pelatihan keterampilan Shibori.

\section{Hasil dan Pembahasan}

Program pengabdian masyarakat melalui Program Kemitraan Masyarakat ini dilaksanakan dengan beberapa kegiatan. Gambaran program yang dilaksanakan adalah sebagai 
berikut:

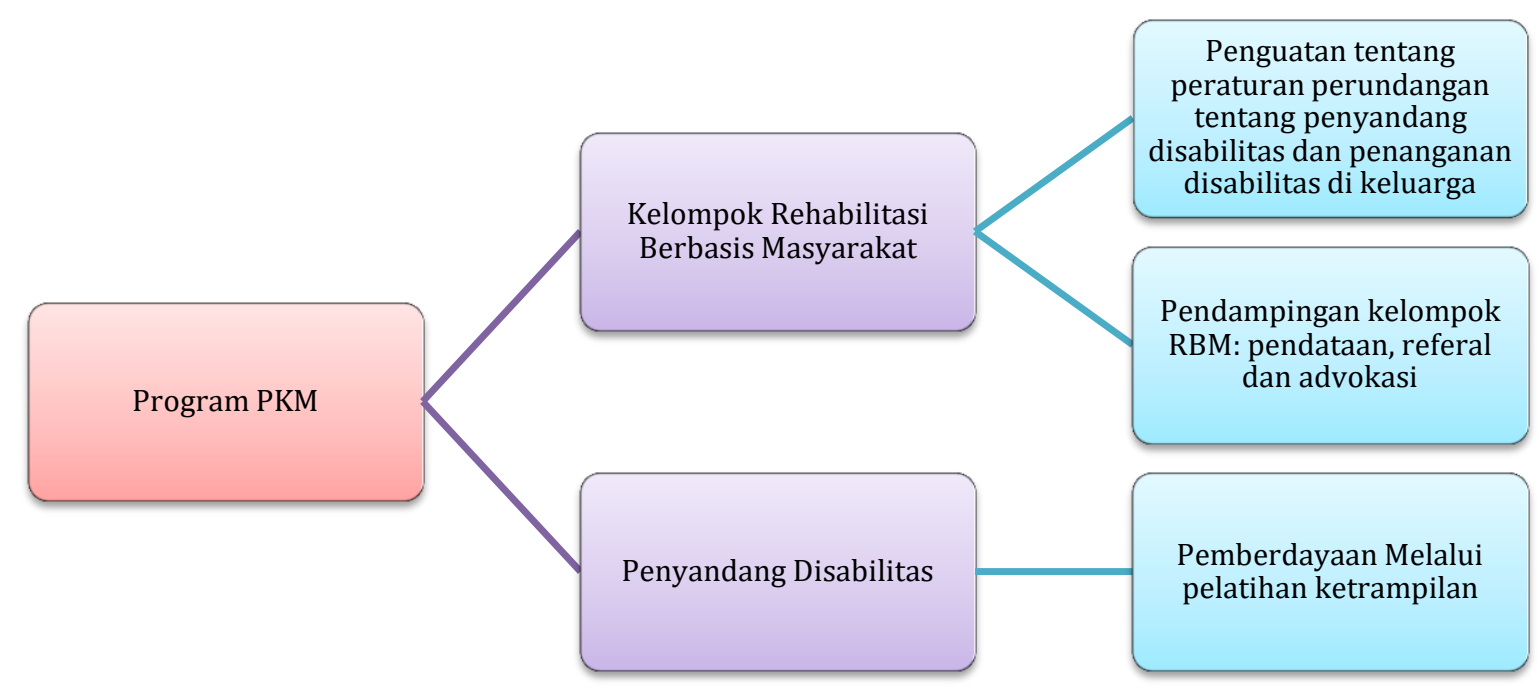

Gambar 1. Program Kemitraan Masyarakat di Desa Panggungharjo Sewon Bantul Yogyakarta

\section{a. Pelaksanaan Penguatan Kelompok Rehabilitasi Berbasis}

Masyarakat memahami berbagai isu tentang permasalahan penyandang disabilitas, khususnya terkait rehabilitasi sosial kelompok rehabilitasi berbasis masyarakat yang beranggotakan kader PKK dan penyandang disabilitas, dan perwakilan pemerintah desa mendapatkan pemahaman tentang peraturan perundangan tentang pemenuhan hak penyandang disabilitas, pemahaman tentang cara penanganan penyandang disabilitas, sertaperan komunitas untuk upaya penghapusan kekerasan terhadap perempuan dan anak disabilitas. Kelompok Rehabilitasi Berbasis Masyarakat diperkenalkan oleh peraturan perundangan tingkat internasional yaitu Konvensi Hak Asasi Penyandang Disabilitas (United Nation Convention of The Rights of Persons With Disabilities/UN-CRPD), sebagaimana tertuang pada UU No. 19 tahun 2011 [4] yang merupakan pengesahan konvensi UN-CRPD, UU No. 8 tahun 2016 [5] yaitu tentang Penyandang Disabilitas; Perda Provinsi Daerah Istimewa Yogyakarta No. 4 [6] tentang Perlindungan dan Pemenuhan Hak Penyandang Disabilitas,serta Perda Kabupaten Bantul No. 11 tahun 2015 [7] tentang Pemenuhan Hak-Hak Penyandang Disabilitas. Berdasarkan pemahaman peraturan peraturan perundangan ini kelompok Rehabilitasi Berbasis Masyarakat bisa berpartisipasi dalam kegiatan advokasi guna pemajuan pemenuhan hak penyandang disabilitas kepada pemerintah dan stakeholder lain. Pada kegiatan ini, juga diberikan pemahaman cara penanganan penyandang disabilitas, khususnya yang mengalami gangguan mental sehingga kelompok Rehabilitasi Berbasis Masyarakat ini nantinya dapat memberikan edukasi pada keluarga yang memiliki anggota keluarga yang mengalami gangguan mental. Gambaran pelaksanaan kegiatan sebagai berikut: 

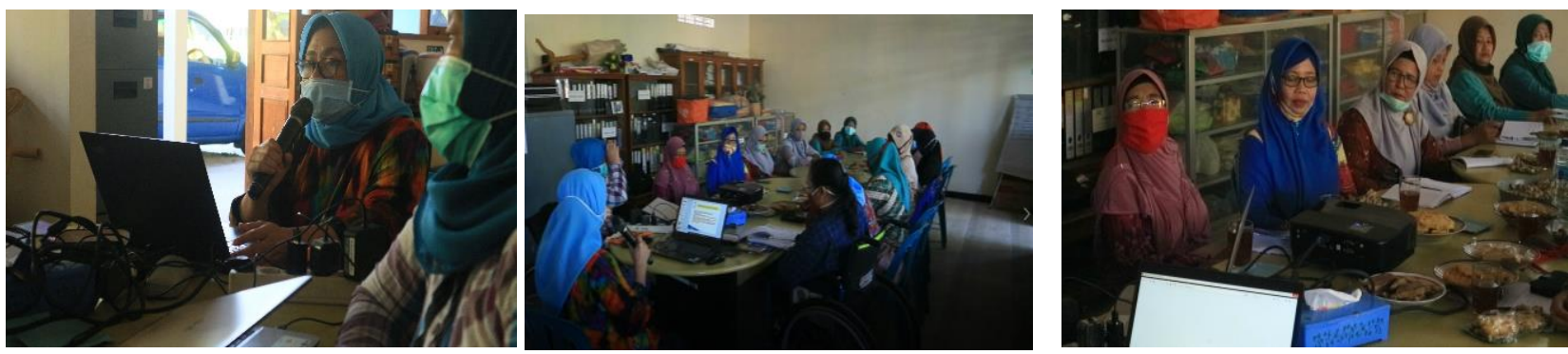

Gambar 2: Pelaksanaan Penguatan Kader Kelompok Rehabilitasi Berbasis

\section{b. Pendampingan Penyusunan Dan Pelaksanaan Program Dan Kegiatan Kelompok Rehabilitasi Berbasis Masyarakat}

Pendampingan penyusunan program dan kegiatan kelompok Rehabilitasi Berbasis Masyarakat melakukan pemutakhiran data, melakukan referal kebutuhan-kebutuhan penyandang disabilitas pada berbagai layanan pemerintah, serta melakukan advokasi untuk pemenuhan hakhak penyandang disabilitas. Pada kegiatan ini, telah dilakukan pendampingan pendataan penyandang disabilitas di Desa Panggungharjo dengan menggunakan basis dusun. Kader Rehabilitasi Berbasis Masyarakat dibagi berdasarkan jumlah dusun yang ada. Mereka diberi tanggung jawab untuk melakukan pendataan, dengan formulir pendataan yang telah disusun. Hasil pendataan jumlah penyandang disabilitas dan karaketristiknya adalah sebagai berikut:

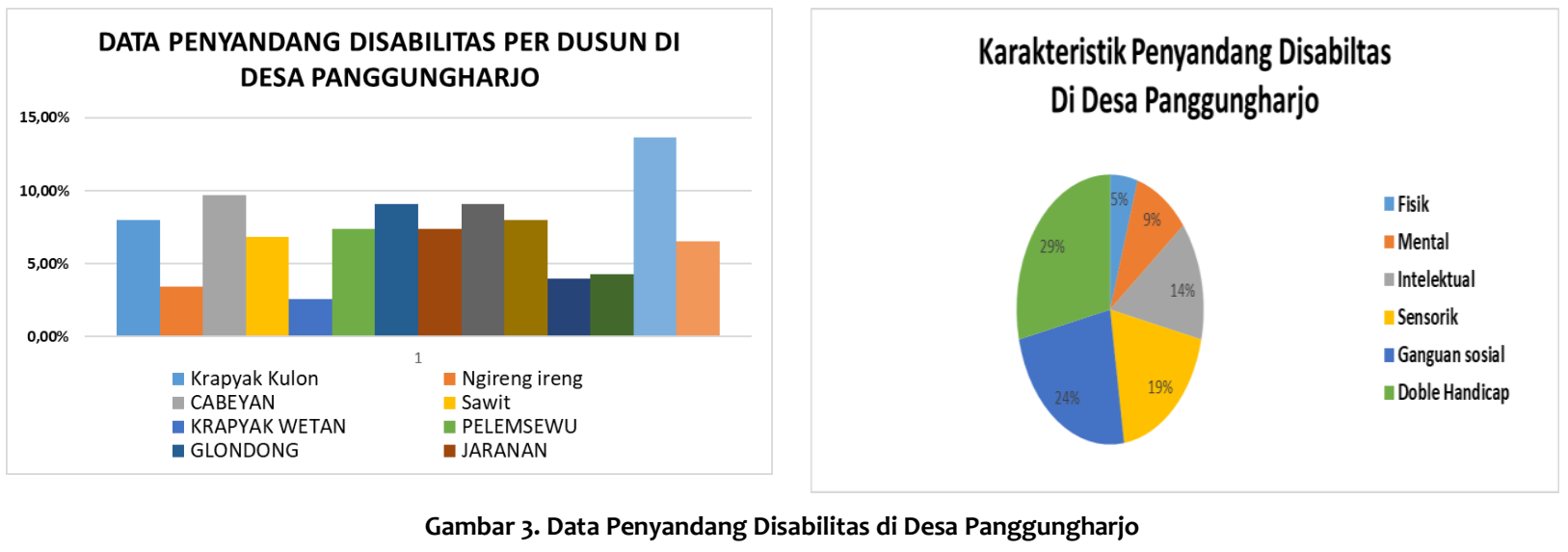

Berdasarkan data yang ada Dusun Kweni mmenunjukkan dusun dengan jumlah disabilitas terbanyak, dengan disabilitas tertinggi berada pada penyandang disabilitas fisik kemudian diikuti penyandang disabilitas mental dan intelektual. Berdasarkan pendataan yang dilakukan oleh kader Rehabilitasi Berbasis Masyarakat ini, ada 351 orang. Kelompok Rehabilitasi Berbasis Masyarakat ini juga telah berhasil melakukan referral dengan berjejaring pada berbagai layanan yang ada di masyarakat untuk memenuhi kebutuhan penyandang disabilitas. Kegiatan referral yang dilakukan antara lain adalah berjejaring dengan berbagai layanan dalam masyarakat untuk mendapatkan alat bantu mobilitas. Kelompok Rehabilitasi Berbasis Masyarakat ini bisa mendapatkan kursi roda dan bantuan sembako bagi keluarga yang terdampak pandemi Covid-19. Kursi roda telah dapat mengubah kehidupan seorang disabilitas yang tadinya hanya dibiarkan berbaring di tempat tidur. Dengan kursi roda yang berhasil diakses, penyandang disabilitas ini bias menikmati kehidupan di luar kamar. Gambaran hasil kegiatan referral adalah sebagai berikut: 

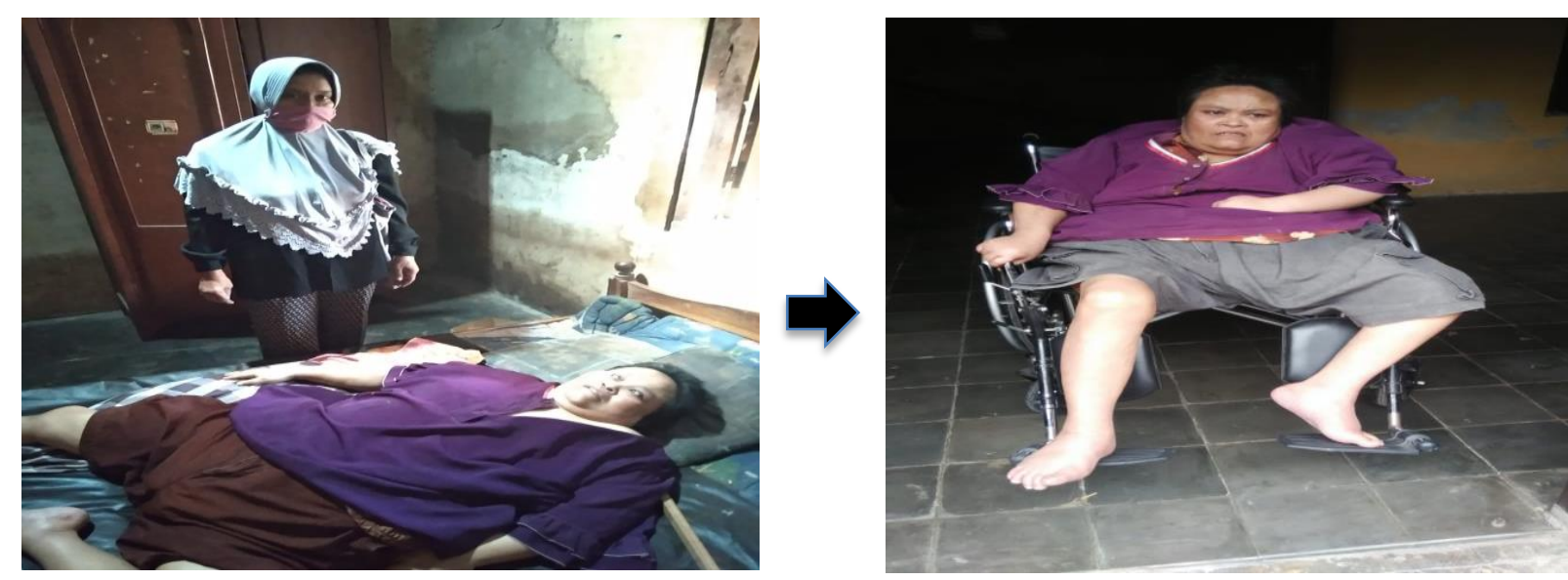

Gambar 4: Kegiatan Referal Untuk Pemenuhan Kebutuhan Alat Mobilitas Penyandang Disabilitas

Pandemi Covid-19 juga telah memberikan dampak yang berat bagi keluarga penyandang disabilitas. Program PKM ini berusaha meringankan beban mereka dengan berjejaring dengan pengusaha untuk mendapatkan bantuan sembako. Pada kegiatan meringankan keluarga disabilitas, kelompok rehabilitasi berbasis masyarakat bisa mendistribusikan 170 bingkisan bantuan masyarakat pada keluarga disabilitas.
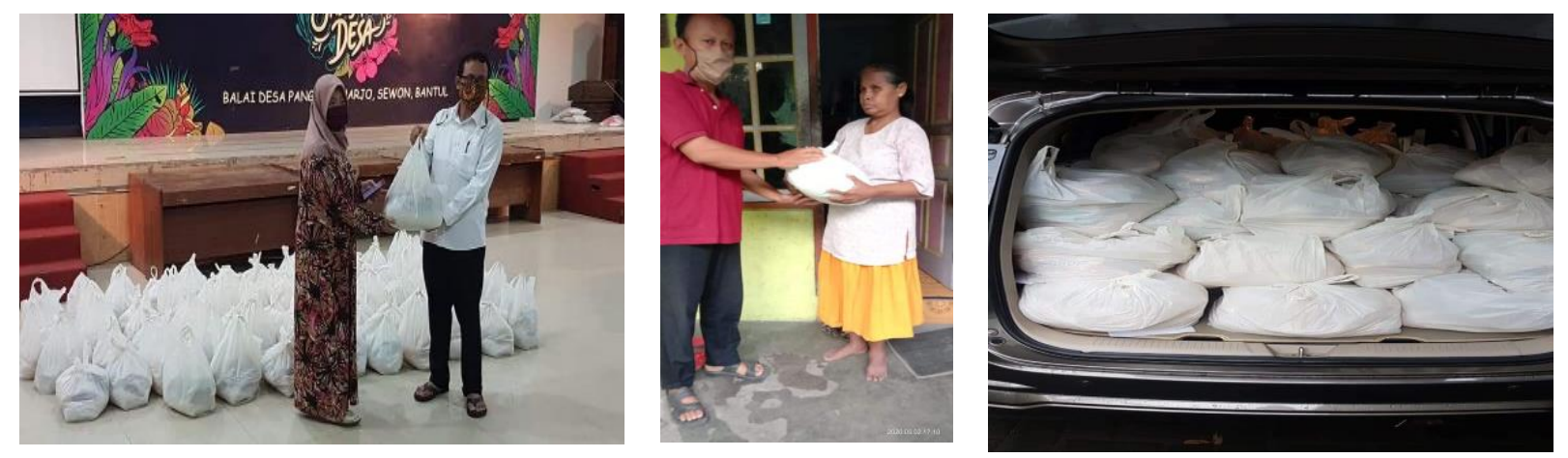

Gambar 5. Distribusi bantuan sembako pada keluarga disabilitas yang terdampak pandemic Covid-19

\section{c. Pemberdayaan Penyandang Disabilitas}

Pemberdayaan penyandang disabilitas dan keluarganya meningkatan kapasitas dan membangun kemandirian untuk meningkatkan kesejahteraannya melalui pelatihan keterampilan pada penyandang disabilitas sehingga mereka memiliki kemandirian secara ekonomi. Pelatihan yang diberikan adalah pelatihan keterampilan Shibori. Keterampilan membuat shibori ini berasal dari Jepang, shibori berasal dari kata kerja shiboru, yakni merupakan teknik pewarnaan kain yang mengandalkan ikatan dan celupan. Motif yang dihasilkan seringkali tidak jauh berbeda dengan batik meskipun dari segi pengerjaan lebih mudah dan sederhana. Tidak heran jika jenis kain yang satu ini acap kali disebut dengan "batik" asal Jepang. Teknik shibori ini telah digunakan sejak zaman kekaisaran Jepang beberapa ratus tahun yang lalu. Bahkan, beberapa pewarna alami dapat bertahan 600 tahun lamanya. Konsep pembuatannya pun juga serupa dengan teknik tie dye yang mengandalkan teknik ikat celup. Dengan teknik ini, beberapa kain "dilindungi" agar tidak terkena corak pewarna sehingga pada hasil akhirnya tercipta pola sesuai dengan bagian yang diwarnai dan yang tidak diwarnai. Teknik pembuatan batik shibori mirip dengan batik sebagaimana di Indonesia, yakni dengan menahan warna melalui lilin. Namun, batik shibori menahan warna dengan menggunakan lilitan dan teknik lipatan. Keterampilan ini 
cukup mudah untuk dilakukan penyandang disabilitas karena tidak memerlukan tenaga yang besar, tetapi lebih memerlukan ketelatenan. Ada banyak teknik shibori yang bisa dipilih, tetapi karena keterbatasan waktu, pada pelatihan ini, hanya mempraktikkan dua macam teknik shibori, yaitu lipatan segitiga dan segiempat. Gambaran pelatihan shibori ini adalah sebagai berikut:

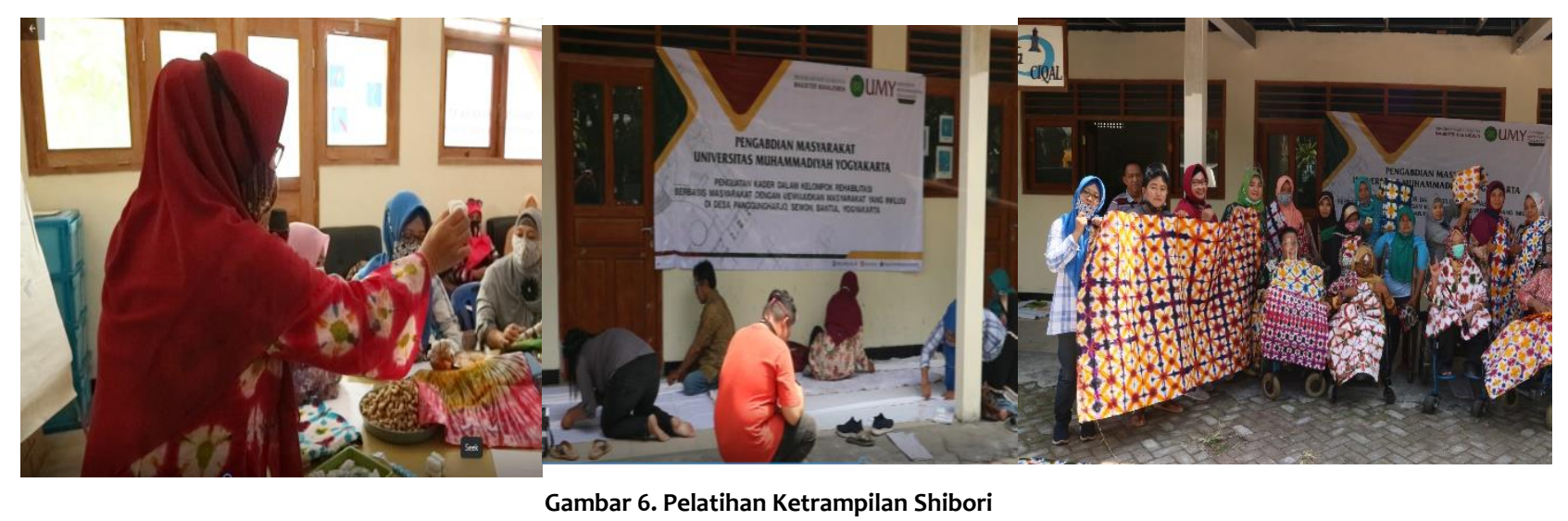

Peserta pelatihan ini diharapkan dapat mengembangkan teknik pembuatan yang lain pada kesempatan yang lain. Potensi batik shibori ini dapat dipasarkan di Yogyakarta yang merupakan kota pariwisata. Kegiatan pelatihan keterampilan ini dilaksanakan secara inklusi, yaitu kader Rehabilitasi Berbasis Masyarakat dan penyandang disabilitas. Harapannya peserta pelatihan ini nantinya bisa menjadi pelatih untuk anggota masyarakat lain di Desa Panggungharjo. Keterampilan ini juga menjadi potensi menambah penghasilan penyandang disabilitas, tidak hanya menghasilkan kain shibori, tetapi juga produk pengembangannya seperti menjadi bahan untuk industri konveksi.

\section{Simpulan}

Kader Kelompok Rehabilitasi Berbasis Masyarakat di Desa Panggungharjo merupakan kader dari kelompok yang melibatkan penyandang disabilitas dan keluarganya, tokoh masyarakat, PKK, dan pemerintah desa sebagai koordinator dan sekaligus melakukan supervisi. Hasil kegiatan menunjukkan kelompok rehabilitasi berbasis masyarakat ini telah memberikan kemanfaatan bagi peningkatan kesejahteraan penyandang disabilitas melalui pendataan, referral dan advokasi. Program ini juga memberdayakan penyandang disabilitas, keluarganya melalui peningkatan kapasitas, membangun kemandirian, serta pengembangan upaya preventif dan promotif bagi masalah disabilitas masih perlu ditingkatkan dalam upaya melalukan rehabilitasi social melalui pemberian pelatihan ketrampilan shibori.

\section{Ucapan Terima Kasih}

Pada Program Kemitraan Masyarakat ini didukung oleh Universitas Muhammadiyah Yogyakarta yang telah memberikan dukungan materiil dan nonmateriil.. Ucapan terima kasih terutama kepada pemberi dana, yaitu Universitas Muhammadiyah Yogyakarta berdasarkan nomor kontrak 031/PEN-LP3M/I/2020. Ucapan terima kasih juga diberikan kepada Bapak Wahyudi selaku Kepala Desa Panggungharjo yang telah mendukung program Rehabilitasi 
Berbasis Masyarakat dan kader kelompok Rehabilitasi Berbasis Masyarakat serta penyandang disabilitas yang telah berperan serta dalam pelaksanaan kegiatan PKM di Desa Panggungharjo Sewon Bantul Yogyakarta.

\section{Daftar Pustaka}

http://www.panggungharjo.desa.id//(diunduh 4 Juli 2018)

http://arifrohmansosialworker.blogspot.com/2011/02/rehabilitasi-sosial-berbasiskan.html (diunduh 5 Januari 2012)

http://www.ncda.gov.ph/international-conventions-and-commitments/otherinternationalcommitments/biwako-millennium-framework/ (diunduh 4 Juli 2018).

Republik Indonesia. 2011. Undang-Undang Nomor 19 tahun 2011 tentang Pengesahan Convention on the Rights of Persons with Disabilities (Konvensi mengenai Hak-Hak Penyandang Disabilitas). Lembaran Negara Republik Indonesia Tahun 2011 Nomor 107. Sekretariat Negara. Jakarta.

Republik Indonesia. 2016. Undang-undang No 8 Tahun 2016 tentang Penyandang Disabilitas (Lembaran Negara Republik Indonesia Tahun 2016 Nomor 69.

Republik Indonesia. 2012. Peraturan Daerah Provinsi Daerah istimewa Yogyakarta Nomor 4 Tahun 2012 tentang Perlindungan dan Pemenuhan Hak-Hak Penyandang Disabilitas. Lembaran Daerah Provinsi Daerah Istimewa Yogyakarta Tahun 2012 Nomor 4. Sekretariat Daerah Provinsi Daerah Istimewa Yogyakarta. Yogyakarta

Republik Indonesia. 2015. Peraturan Daerah Provinsi Kebupaten Bantul Nomor 11 Tahun 2015 tentang Pemenuhan Hak-Hak Penyandang Disabilitas. Lembaran Daerah Kabupaten Bantul Tahun 2015 Nomor 53. Sekretariat Daerah Kabupaten Bantul Yogyakarta

Surwanti., Arni. 2018. Economic Empowerment Through Entrepreneurship Based On Local Regulation Of Protection And Fulfillment The Rights Of Persons Of Disabilities In Yogyakarta Province. Working Paper.

Surwanti., Arni., Warih Andan Puspitosari., 2019. Peningkatan Peran Kelompok Rehabilitasi Berbasis Masyarakat Dalam Mewujudkan Kesejahteraan Penyandang Disabilitas. Jurnal Pemberdayaan: Publikasi Hasil Pengabdian kepada Masyarakat Vol. 3, No. 3, Desember 2019, Hal. 305-314 ISSN: 2580-2569; e-ISSN: 2656-0542 DOI: https://doi.org/10.12928/jp.v3i3.1105

World Health Organization. 2010. CBR guidelines Introductory booklet. WHO Library Cataloguing-in-Publication Data. ISBN 9789241548052 